\title{
Irrigation Timing Relative to Head Development Influences Yield Components, Sugar Levels, and Glucosinolate Concentrations in Cabbage
}

\author{
Theodore J.K. Radovich, Matthew D. Kleinhenz ${ }^{1}$, and John G. Streeter \\ Department of Horticulture and Crop Science, The Ohio State University, Ohio Agricultural Research \\ and Development Center (OARDC), 1680 Madison Avenue, Wooster, OH 44691-4096
}

\begin{abstract}
AdDitional INDEX WORDS. evapotranspiration, isothiocyanates, flavor, quality, secondary metabolism, stress, vegetables, water deficit

Aвstract. To better understand the influence of environmental factors on components of crop productivity and nutritional and sensory quality parameters, the fresh-market cabbage (Brassica oleracea L. Capitata Group) 'Bravo' was irrigated at different periods relative to head development in 2002 and 2003 at the Ohio Agricultural Research and Development Center in Wooster. Irrigation was provided to plots either: 1) from planting to maturity, 2) during frame development only, or 3) during head development only. Control plants received no irrigation after plant establishment. Irrigation timing relative to crop stage significantly affected all head characteristics with the greatest differences between cabbage receiving irrigation during head development and cabbage not irrigated during head development. On average, heads from cabbage irrigated during head development were heavier, larger, less pointed, and had less volume occupied by the core than heads from cabbage not irrigated during head development. A positive, linear relationship $\left(r^{2}=0.89\right)$ was found between head volume and head weight. Across years, combined head fructose and glucose concentrations were significantly greater and sucrose concentrations significantly lower in cabbage receiving irrigation during head development than in cabbage not irrigated during head development. Total and individual glucosinolate levels were greater in cabbage not irrigated during head development relative to cabbage receiving irrigation during head development. Head weight, fructose and glucose were positively related to the proportion of estimated crop evapotranspiration replaced by irrigation during head development, while the opposite response was observed in head sucrose and total and indole glucosinolate concentrations.
\end{abstract}

Linkages between plant metabolic processes and environmental factors may be exploited to manipulate crop yield, flavor, and nutritional quality (Hochmuth, 2003; Lester and Crosby, 2002; Rosenfeld, 1999). In cabbage, planting date influences yield components, sugar levels, and glucosinolate concentrations, and may affect fresh cabbage flavor (Kleinhenz and Wszelaki, 2003; Radovich et al., 2004a; Rosa et al., 2001). This planting date effect is thought to result from separate and interactive effects of canopy temperature and plant water status during head development (Bible et al., 1980; Radovich et al., 2004a; Rosa et al., 1996). Applying irrigation to mitigate plant stress, specifically during head development, may assist in the management of multiple aspects of cabbage quality, including yield and flavor (Radovich et al., 2004b). However, most studies regarding the influence of irrigation on cabbage quality focused on a limited number of variables, primarily those contributing to yield (Singh and Alderfer, 1966; Swiader et al., 2002), while not accounting for effects on other important variables such as sugar and glucosinolate concentrations. Still, more needs to be learned regarding irrigation

Received for publication 12 Jan. 2005. Accepted for publication 6 Apr. 2005. Manuscript number HCS05-26. Salaries and research support provided in part by State and Federal funds appropriated to the Ohio Agricultural Research and Development Center(OARDC), The Ohio State Univ. Work also supported in part by grants from the Ohio Vegetable and Small Fruit Research and Development Program and OARDC Research Enhancement Competitive Grants Program. We thank Dr. Seppo Salminen for his assistance with HPLC analysis, John Elliott, Nate Honeck, Jim Sonowski, and Aparna Gazula for their technical assistance, Rothert Farm for assistance with plant material and Drs. Jim Metzger and Joe Scheerens for their critical review of the manuscript. Use of trade names does not imply endorsement of the products named nor criticism of similar ones not named.

'Corresponding author; e-mail kleinhenz.1@osu.edu effects on physical aspects of overall cabbage head quality. For example, the relationship between head volume and weight is important because it allows for the prediction of yield based on individual head size. A strong, positive relationship appears to be stable across a range of genotypes, environments, and development stages (Kleinhenz, 2003; Kleinhenz and Wszelaki, 2003; Radovich and Kleinhenz, 2004; Radovich et al., 2004c; Wszelaki and Kleinhenz, 2003). However, the influence of irrigation on this relationship has not been reported.

As production approaches levels adequate to meet demands for fresh-market cabbage, focus has shifted to head characteristics influencing buyer- and consumer-oriented assessments of crop quality (Kuchenbach et al., 1999; Radovich et al., 2003). Sensory quality properties are important because cabbage is the primary ingredient in cole-slaw and other salads (Martens, 1985; Radovich, 2004b). Most important among fresh cabbage sensory characteristics are the flavor attributes pungency and sweetness, which are strongly influenced by glucosinolate and sugar concentrations, respectively (van Doorn et al., 1998; Yano et al., 1987).

Of the sugars present in cabbage heads, fructose, glucose, and sucrose comprise the majority and account for $\approx 20 \%$ to $40 \%$ of the total mass of cabbage heads on a dry weight basis (Janes, 1950; Rosa et al., 2001). Yet, the factors influencing sugar concentrations in cabbage are poorly understood. Rosa et al. (2001) reported that planting date influences fructose, glucose, and sucrose concentrations in cabbage and broccoli (Brassica oleracea Italica Group), with higher sugars in heads of plants grown in Portugal in the fall. Janes (1950) reported that greater irrigation frequency increased the concentrations of total reducing sugars in heads of a single cabbage cultivar, and that the effect of irrigation depended on the season of growth. 
Glucosinolates are amino acid-derived secondary plant metabolites of considerable scientific and practical interest. The hydrolysis products of glucosinolates may exhibit antibiotic, goitrogenic, anti-carcinogenic, or organoleptic activity (Fahey et al., 2001). Sinigrin and progoitrin are the most important compounds with regard to flavor, since they are the primary determinants of pungency, bitterness and sulfurous aroma in cabbage (Buttery et al., 1976; van Doorn et al., 1998).

Glucosinolate responses to planting date indicate that their levels in cabbage are influenced by abiotic growth factors (Bible et al., 1980; Radovich et al., 2004c; Rosa et al., 1996). Supra-optimal temperatures increase the concentrations of glucosinolates in tissues of Brassica L. species (Charron and Sams, 2004; Pereira et al., 2002) and frequent, high-temperature stress during head development is associated with high glucosinolate concentrations in heads of field-grown cabbage (Radovich et al., 2004c; Rosa et al., 1996).

Maximizing plant capacity for transpiration-mediated leaf cooling through irrigation may mitigate plant heat stress responses (Hermann et al., 1990; Jiang and Huang, 2001), including, perhaps, elevations in secondary metabolites. Bible et al. (1980) reported that irrigation can eliminate seasonal variation in head concentrations of thiocyanate (a gucosinolate hydrolysis product), while Freeman and Mossadeghi (1973) showed that soil moisture stress increased the concentrations of allyl isothiocyanate (a product of sinigrin hydrolysis) 4-fold relative to well-watered plants. However, as with sugars, the relative response of individual glucosinolates in cabbage heads to supplemental irrigation is not known.

The objective of this study was to document the influence of irrigation timing (relative to head development) on important indicators of cabbage head physical and chemical quality, including yield components, sugar levels, and glucosinolate concentrations.

\section{Materials and Methods}

Plant material, eXPerimental site, and design. Greenhousegrown seedlings of the commercial cabbage variety 'Bravo' with approximately four true leaves were transplanted to the field 10 June 2002 and 17 June 2003 at the Ohio Agricultural Research and Development Center (OARDC) in Wooster, Ohio (lat. $40^{\circ} 47^{\prime} \mathrm{N}$, long. $\left.81^{\circ} 55^{\prime} \mathrm{W}\right)$ using a single-row mechanical transplanter. Soil at the site was a Fine-loamy, Mixed, Mesic, Typic Fragiuldalf. Plant spacing in both years was $0.31 \mathrm{~m}$ within single $18-\mathrm{m}$-long rows with $1.5 \mathrm{~m}$ between treatment rows. Pre-plant fertilizer applications were: $560 \mathrm{~kg} \cdot \mathrm{ha}^{-1}$ of $10 \mathrm{~N}-8.7 \mathrm{P}-16.6 \mathrm{~K}$ (2002) and 448 $\mathrm{kg} \cdot \mathrm{ha}^{-1}$ of $19 \mathrm{~N}-8.3 \mathrm{P}-15.8 \mathrm{~K}$ (2003). Standard pest management strategies, based on scouting, thresholds, and application of labeled pesticides, were employed. The field experiment was arranged in a randomized complete-block design with five replications. The irrigation treatments were: irrigation throughout plant development [no stress (NS)], irrigation during frame development only [head stress (HS)], and irrigation during head development only [frame stress (FS)]. Control plants [frame and head stress (FHS)] received no irrigation following a 2 -week establishment period in the field. Irrigation was withheld from the FS treatments 14-51 and 14-55 d after planting (DAP) in 2002 and 2003, respectively. Irrigation was withheld from the HS treatments 50-86 and 55-86 DAP in 2002 and 2003, respectively, beginning when $>50 \%$ of all treatment plants had initiated heading. Drip irrigation tape (340 $\mathrm{L} \cdot \mathrm{m}^{-1} \cdot \mathrm{h}^{-1}$; T-Systems International, San Diego, Calif.) was laid within $8 \mathrm{~cm}$ of the base of seedlings in irrigated rows. Valved connectors allowed for watering of individual rows by turning valves on or off as necessary. Line pressure was regulated to 70 $\mathrm{kPa}$. Irrigation treatments were initiated following an establishment period ( 2 weeks) during which all plants were irrigated. During the treatment period, irrigation was applied when soil sampled at a depth of $18 \mathrm{~cm}$ was unable to maintain its shape when formed into a ball in hand, a method of scheduling chosen for its simplicity, popularity, and reliability on various soil types (Heermann et al., 1990; Klocke and Fischbach, 1984). Irrigation episodes lasted 3-5 h. Soil moisture was monitored occasionally at $18 \mathrm{~cm}$ using gypsum blocks (Delmhorst, Towaco, N.J.), time domain reflectometry (TDR-300; Spectrum Technologies, Plainfield, Ill.) or gravimetrically.

EVAPOTRANSPIRATION CALCULATION. Temperature, light intensity, wind speed and relative humidity data were collected hourly $\approx 400 \mathrm{~m}$ from the experimental site by the OARDC Weather System (The Ohio State Univ., 2003). Reference evapotranspiration $\left(\mathrm{Et}_{\mathrm{o}}\right)$ was calculated with the Daily Reference Evapotranspiration Calculator (Univ. of California, Davis) employing the FAO modified Penman-Monteith equation (Allen et al., 1998; Snyder and Eching, 2004). Crop evapotranspiration $\left(\mathrm{ET}_{\mathrm{c}}\right)$ was calculated using the equation $\mathrm{ET}_{\mathrm{c}}=\mathrm{K}_{\mathrm{c}} \times \mathrm{Et}_{\mathrm{o}}$, where $\mathrm{K}_{\mathrm{c}}$ is the crop coefficient. An adjusting $\mathrm{K}_{\mathrm{c}}$ was used during frame development, beginning at 0.7 and increasing $8.75 \times 10^{-3}$ per day until head development. Thereafter, transpiration rate stabilizes and a constant $\mathrm{K}_{\mathrm{c}}$ of 1.05 was used (Allen et al., 1998; Nelson and Hwang, 1976).

HARVEST AND EVALUATION OF YIELD COMPONENTS. Six adjacent heads were harvested from a randomly selected position in each row 86DAP. Physical characteristics were immediately recorded on one group of three heads. Head weight was taken with a commercial field scale (A\&D Engineering, Milpitas, Calif.). Head diameter was measured in two directions; stem end to apex (polar) and perpendicular to the polar transect (equatorial). Head shape was expressed as the ratio of the polar diameter to equatorial diameter $(\mathrm{P}: \mathrm{E})$, where $1.0=$ round. Volume was calculated from mean head diameter values as previously reported (Radovich and Kleinhenz, 2004). Head dry matter concentration was calculated as a percent of fresh tissue total weight by dividing the dry weight (recorded after drying for $7 \mathrm{~d}$ at $70^{\circ} \mathrm{C}$ ) of a section (core removed) of each head by its fresh weight and multiplying by 100 . The second group of heads was held in net bags in darkened storage at $7{ }^{\circ} \mathrm{C}$ for $<48 \mathrm{~h}$, after which individual head weight and diameter were recorded and head tissue was processed for chemical analysis as previously described (Radovich et al., 2004c).

Sugar analysis. Head tissue sugar concentrations were determined by gas-liquid chromatography using the method of Streeter and Strimbu (1998). Ground, freeze-dried cabbage tissue (4 mg) was placed in 2-mL vials, to which was added $125 \mu \mathrm{L}$ pure pyridine and $125 \mu \mathrm{L} \mathrm{STOX} \mathrm{reagent}\left(25 \mathrm{mg} \cdot \mathrm{mL}^{-1}\right.$ hydroxylamine hydrochloride and $6 \mathrm{mg} \cdot \mathrm{mL}^{-1}$ phenyl-D-glucopyranaside). The mixtures were vortexed and heated at $70^{\circ} \mathrm{C}$ for $40 \mathrm{~min}$, during which time the mixtures were vortexed three more times. The mixture was allowed to cool, after which $200 \mu \mathrm{L}$ hexamethyldisalazane (HMDS) plus $20 \mu \mathrm{L}$ trifluoroacetic acid (TFA) were added, thoroughly mixed, and allowed to incubate for $60 \mathrm{~min}$ at ambient temperature. Injection volume was $1 \mathrm{~mL}$ and TMS-oxime derivatives were separated on a packed column of 3\% OV-17 on Chromsorb WHP using a Hewlett-Packard 5890 Series II gas chromatograph (Hewlett-Packard, Palo Alto, Calif.). Peak areas were quantified using a Hewlett-Packard 3396A integrator. Sugar concentrations were quantified from peak areas using previously established standard curves. 
GLuCosinolate analysis. Total glucosinolate concentrations in freeze-dried cabbage head tissue were determined using the glucose evolution procedure of Heaney and Fenwick (1981), with some modifications as previously described (Radovich et al., 2004a). Individual glucosinolate concentrations in methanol extracts used for the glucose evolution procedure were analyzed by HPLC employing the method of the International Organization for Standards (ISO, 1992), with some modifications. Sample extract ( $1 \mathrm{~mL}$ ) was applied to $0.5 \mathrm{~mL}$ of swollen Sephadex A-25 resin (Sigma Chemical Co., St. Louis) and washed with water and pyridine-acetate buffer (Radovich et al., 2004a). Sulfatase (1.25 $\mathrm{U}$ in $250 \mu \mathrm{L}$ of $0.02 \mathrm{M}$ pyridine-acetate buffer) from Helix pomatia L. (Sigma Chemical Co.) was applied to the column and allowed to incubate for $16 \mathrm{~h}$ at ambient temperature. Desulphoglucosinolates were eluted with $1 \mathrm{~mL}$ of water and the eluate (1.25 mL total volume) transferred to $2 \mathrm{~mL}$ vials. Samples were stored at $<0{ }^{\circ} \mathrm{C}$ for $<24 \mathrm{~h}$ prior to analysis. Desulphoglucosinolates in $5 \mu \mathrm{L}$ of sample extract were separated by reverse phase high performance liquid chromatography (HPLC) using a Waters (Waters, Milford, Mass.) HPLC system and a $250 \times 2.1 \mathrm{~mm}$ Supelcosil LC-18 $5 \mu \mathrm{m}$ column (Supelco, Bellefonte, Pa.). The mobile phase was $\mathrm{H}_{2} \mathrm{O}$ (A) and $20 \%$ aqueous acetonitrile (B) at 99\% A for $1 \mathrm{~min}$, followed by a 20 min linear gradient to $99 \%$ $\mathrm{B}$, then a linear gradient over 2 min to $99 \%$ A that was held for $18 \mathrm{~min}$. The flow rate was $0.27 \mathrm{~mL} \cdot \mathrm{min}^{-1}$. Column temperature was maintained at $30^{\circ} \mathrm{C}$. Eluting compounds were detected using a Waters 996 Photo Array Detector at a scanning wavelength range of 210-400 nm. Desulfoglucosinolates were identified and quantified using authentic 2-propenyl (sinigrin), 3-methylsulfinylpropyl (glucoiberin), 2(R)-2-hydroxy-3-butenyl (progoitrin), and benzyl glucosinolate standards (KVL, Frederiksberg, Denmark) and published chromatograms and response factors (ISO, 1992). In the absence of commercially available product, glucobrassicin was identified based on peak position and size relative to the available standards above (ISO, 1992; Rosa et al., 1997).

Statistical analysis. Data were analyzed with the General Linear Model procedure of SAS for Windows v.8 (SAS Inst., Cary, N.C.) and with the Regression Wizard of SigmaPlot 2000 for Windows v. 6.0 (SPSS, Chicago).

\section{Results}

Climatic Data. Estimated $\mathrm{ET}_{\mathrm{c}}$, average daily temperature, and the amount of water received by treatment plots for 7-d periods from planting to harvest are shown in Fig. 1. Gravimetric and volumetric soil moisture across treatments ranged between $8 \%$ to $21 \%$ and $14 \%$ to $35 \%$, respectively, depending on the amount of water received. In 2002, temperatures and $\mathrm{ET}_{\mathrm{c}}$ were higher and water received was less than in 2003. This resulted in a smaller proportion of the estimated crop water requirement being supplied as rainfall and irrigation in 2002 than 2003 during both frame and head development.

Physical head traits. The main and interactive effects of year $(\mathrm{Y})$ and irrigation treatment (I) were significant for all but one (density) of the physical traits measured, with density influenced only by year (Table 1). Overall, treatment (I) differences were greater in 2002 than 2003. In both years, head size and weight were greatest in treatments receiving irrigation during head development (NS and FS, Table 1). In 2002, heads from NS plots were only $2 \%$ larger, but were $20 \%$ heavier than heads from FS plots (Table 1). There was no difference in head size or weight between NS and FS treatments in 2003, although heads

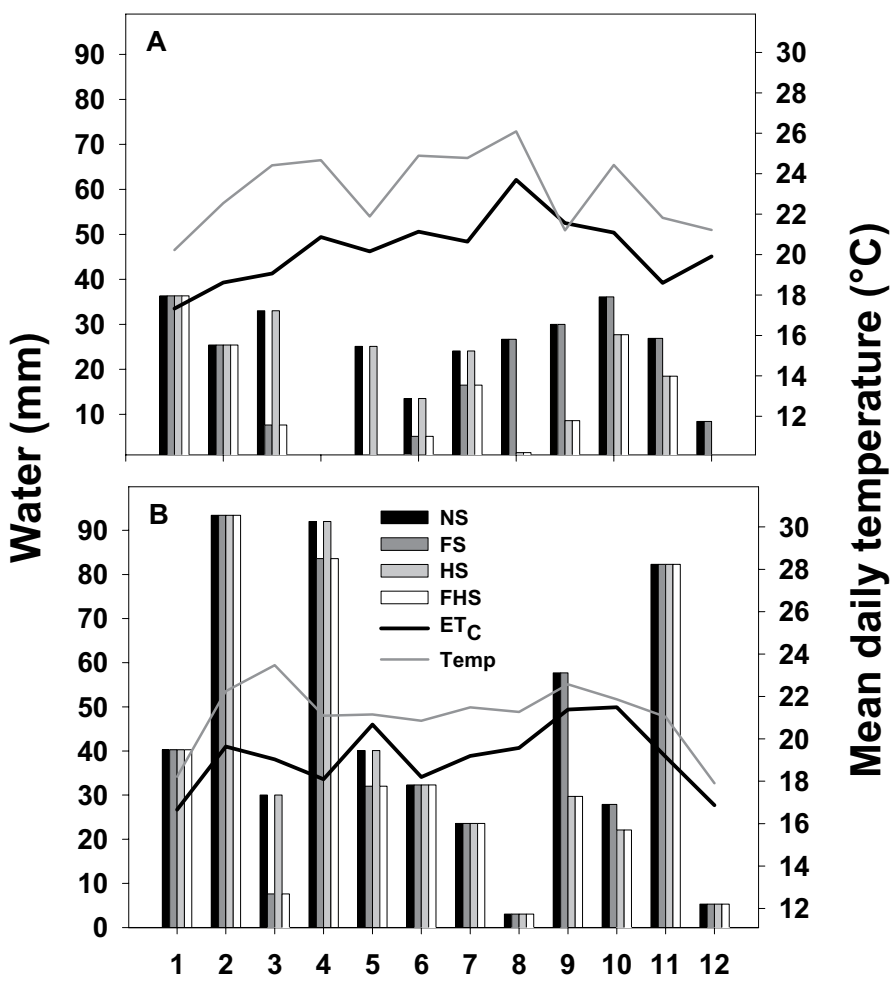

\section{Week after planting}

Fig. 1. Total water received, crop evapotranspiration $\left(\mathrm{ET}_{\mathrm{c}}\right)$, and mean daily temperature (temp) during the development of 'Bravo' cabbage planted 10 June 2002 (A) and 17 June 2003 (B) at the Ohio Agricultural Research and Development Center in Wooster. NS = irrigation provided throughout plant development, HS = irrigation provided during frame development only, FS = irrigation provided during head development only, FHS = no irrigation provided for the duration from establishment to harvest. FHS treatment bars indicate the amount of water received as rainfall during each period.

from those treatments were $15 \%$ heavier than heads from HS and FHS plots. Heads were, on average, $35 \%$ heavier and $45 \%$ larger in 2003 than 2002. Across Y and I there was a strong $\left(r^{2}=0.88\right)$ relationship between head size (volume) and weight described by the linear equation $\mathrm{W}=(0.0007 \times \mathrm{V})+0.12$, where $\mathrm{W}=$ head weight $(\mathrm{kg})$ and $\mathrm{V}=$ head volume $\left(\mathrm{cm}^{3}\right)$.

Across years, P:E diameter ratios and dry matter concentrations were lowest in heads from plants irrigated during head development (NS, FS). In 2002, these differences followed the order NS $<$ FS $<$ HS $<$ FHS for diameter ratio and NS $=$ FS $<$ HS = FHS for moisture content. In 2003, there was no difference between NS and FS plots in diameter ratio, and only NS differed in diameter ratio from HS and FHS. Also, in 2003, there was no clear treatment effect on percent dry matter. Across treatments, diameter ratio and percent dry matter were $20 \%$ and $40 \%$ lower, respectively, in 2003 than in 2002.

Sugar concentrations. The main and interactive effects of $\mathrm{Y}$ and I were significant for fructose, glucose, and sucrose (Table 2), and the three sugars collectively accounted for $\approx 30 \%$ to $60 \%$ of sample dry weight (data not shown). Across years, heads from plants receiving irrigation during head development were higher in fructose and glucose, and lower in sucrose, than plants not receiving irrigation during head development (Table 2). This tendency was more pronounced in 2002 than 2003, when heads from NS and FS treatments were $\approx 30 \%$ higher in fructose and glucose and $33 \%$ lower in sucrose. Subsequently, the ratio 
Table 1. Head characteristics and analysis of variance for the influence of year and irrigation on head traits in 'Bravo' cabbage planted 10 June 2002 and 17 June 2003 at the Ohio Agricultural Research and Development Center in Wooster. Values are means of five replications \pm SE.

\begin{tabular}{|c|c|c|c|c|c|c|}
\hline Year & $\begin{array}{l}\text { Irrigation } \\
\text { treatment }^{\mathrm{z}}\end{array}$ & $\begin{array}{l}\text { Wt } \\
(\mathrm{kg})\end{array}$ & $\begin{array}{l}\text { Mean } \\
\text { diam } \\
(\mathrm{cm})\end{array}$ & $\begin{array}{l}\text { Diam } \\
\text { ratio }\end{array}$ & $\begin{array}{l}\text { Density } \\
\left(\mathrm{g} \cdot \mathrm{cm}^{-3}\right)\end{array}$ & $\begin{array}{c}\text { Dry } \\
\text { matter } \\
(\%)\end{array}$ \\
\hline \multirow[t]{4}{*}{2002} & NS & $1.61 \pm 0.10$ & $15.5 \pm 0.2$ & $1.00 \pm 0.02$ & $0.81 \pm 0.04$ & $8.6 \pm 0.2$ \\
\hline & FS & $1.34 \pm 0.06$ & $14.7 \pm 0.2$ & $1.06 \pm 0.02$ & $0.80 \pm 0.01$ & $8.6 \pm 0.2$ \\
\hline & HS & $0.71 \pm 0.05$ & $11.6 \pm 0.3$ & $1.13 \pm 0.02$ & $0.82 \pm 0.02$ & $11.9 \pm 0.4$ \\
\hline & FHS & $0.51 \pm 0.03$ & $10.7 \pm 0.3$ & $1.23 \pm 0.02$ & $0.76 \pm 0.02$ & $11.3 \pm 0.2$ \\
\hline \multirow[t]{7}{*}{2003} & NS & $3.04 \pm 0.14$ & $19.8 \pm 0.3$ & $0.86 \pm 0.01$ & $0.74 \pm 0.02$ & $6.6 \pm 0.1$ \\
\hline & FS & $3.08 \pm 0.16$ & $19.7 \pm 0.4$ & $0.87 \pm 0.02$ & $0.76 \pm 0.03$ & $6.3 \pm 0.2$ \\
\hline & HS & $2.78 \pm 0.15$ & $18.9 \pm 0.3$ & $0.90 \pm 0.01$ & $0.78 \pm 0.01$ & $5.7 \pm 0.3$ \\
\hline & FHS & $2.51 \pm 0.17$ & $18.6 \pm 0.3$ & $0.89 \pm 0.01$ & $0.72 \pm 0.04$ & $6.1 \pm 0.3$ \\
\hline & Year (Y) & $* * *$ & $* * *$ & $* * *$ & $* *$ & $* * *$ \\
\hline & Irrigation (I) & $* * *$ & $* * *$ & $* * *$ & NS & $* * *$ \\
\hline & $\mathrm{Y} \times \mathrm{I}$ & $*$ & $* * *$ & $* * *$ & NS & $* * *$ \\
\hline
\end{tabular}

${ }^{2} \mathrm{NS}=$ irrigation provided throughout plant development, $\mathrm{HS}=$ irrigation provided during frame development only, FS = irrigation provided during head development only, FHS = no irrigation provided from establishment to harvest.

NS, $, * * *, * * *$ Nonsignificant or significant at $P \leq 0.05,0.01$, or 0.001 , respectively.

of fructose + glucose to sucrose in HS and FHS plots was lower than that in NS and FS plots. On average, fructose and glucose levels in 2003 were twice those in 2002, and sucrose levels were $28 \%$ lower in 2003 than in 2002.

GLUCOSINOLATE CONCENTRATIONS. The glucosinolates identified in our samples were the methionine-derived sinigrin, glucoiberin and progoitrin, and the tryptophan-derived indolyl-3-methyl glucosinolate (glucobrassicin) (Table 3). Irrespective of Y and I, the relative contribution of individual to total glucosinolate concentrations in cabbage heads was in the order: glucoiberin $>$ sinigrin $>$ glucobrassicin $>$ progoitrin. Small peaks of what was tentatively identified as 4-methoxyglucobrassicin followed glucobrassicin concentrations closely but are not reported here. The main and interactive effects of $\mathrm{Y}$ and I were significant for total and all individual glucosinolate concentrations. The exceptions were sinigrin, which was unaffected by $\mathrm{Y}$, and glucoiberin for which there was no significant $\mathrm{Y} \times \mathrm{I}$ interaction (Table 3). Generally, heads from NS and FS plots were lower in total and individual glucosinolates than those from HS and FHS plots. Although influential in both years, irrigation during head development was most effective in lowering glucosinolates relative to the control (FHS) in 2002, when glucosinolates were, on average, $\approx 40 \%$ lower in NS and FS compared to FHS plots (Table 3 ). This decrease was most notable in glucobrassicin (60\%). Also, in 2002, and in contrast to 2003, there were significant differences between NS and FS treatments. Specifically, methionine-derived glucosinolate concentrations in FS heads were $10 \%$ to $18 \%$ lower than those in NS heads (Table 3). Glucoiberin, progoitrin, and glucobrassicin were 19\%, 63\%, and 152\% higher in 2002 than 2003, respectively.

\section{Discussion}

Physical head traits. Ranges in the size, weight, and diameter ratio recorded here are consistent with those found in previous work, including in experimental and commercial fields (Kleinhenz, 2003; Kleinhenz and Wszelaki, 2003). Irrigation during head development resulted in larger, heavier heads, with relatively low $\mathrm{P}:$ E diameter ratios and dry matter content. Supplying irrigation to provide $\approx 100 \%$ of $\mathrm{ET}_{\mathrm{c}}$ is reported to maximize potential yield in cabbage (Bucks et al., 1974; Sanchez et al., 1994; Tiwari et al., 2003). Our data suggest that replacing daily consumptive use is most important during head development (Table 1, Fig. 2). Although there were no differences among head traits between NS and FS plots in 2003, heads were larger and heavier in NS than FS plots in 2002 (Table 1). ET deficits were greater in $\mathrm{FS}\left(12 \%\right.$ of $\left.\mathrm{ET}_{\mathrm{c}}\right)$ than in NS plots (39\% of $\mathrm{ET}_{\mathrm{c}}$ ) during frame development in 2002, and there was little difference in the amount of water received between the two treatments during frame development in 2003. This suggests that drought during frame development and the earliest stages of head development may influence yield by reducing frame size and restricting growth in the outermost head leaves. Lower P:E diameter ratios, along with overall increases in volume, indicate greater head leaf expansion in the NS and FS plots. Restrictions in head leaf expansion in response to drought stress are likely the main reason that withholding water during head development reduces yield.

The positive relationship between head size and weight across treatments is explained by the consistency in head density (Table 1). Marketable yield in cabbage can be predicted based on the mean head size in a given production area (Kleinhenz, 2003). Data here suggest that the strong, positive relationship between head size and weight is stable across irrigation regime, an observation not previously reported.

SugARS. Allowing for differences in methodology and genotype, concentrations of sugars reported here agree with previous reports (Janes, 1950; Rosa et al., 2001). Across years, the influence of irrigation during head development on sugar concentration was attributed to the proportion of $\mathrm{ET}_{\mathrm{c}}$ supplied to the crop during that period (Fig. 3). Our data agree with Janes (1950), who reported lower levels of reducing sugars in heads of rain-fed cabbage in Florida compared to plants receiving supplemental irrigation. Higher fructose and glucose concentrations in heads from NS and FS plots likely contributed to the flavor differences previously reported between those treatments and the control (FHS) (Radovich et al., 2004b). Additionally, treatment responses of fructose and glucose were negatively related to that of sucrose, resulting in lower monomer : dimer ratios in plants not receiving irrigation during head development. This change in sugar ratio may be significant and reflect a modification of sink strength and/or cell osmotic adjustment in head tissues, possibly through regulation of enzymes involved in sucrose metabolism (Gonzalez et al., 1995; Roitsch, 1999).

GLUCOSINOLATES. The absolute and relative concentrations of glucosinolates recorded here agree with previous reports (Rosa et al., 1996; Van Etten et al., 1980). All of the glucosinolates measured were influenced by irrigation, with glucosinolate levels lowest in heads receiving irrigation during head development. Although previously observed in the reproductive tissues of Brassica napus L. (Champolivier and Merrien, 1996; Mailer and Cornish, 1987), a response of glucosinolate concentrations to stress relative to developmental stage has not been reported in 
Table 2. Fructose, glucose, and sucrose concentrations and analysis of variance for the influence of year and irrigation on sugar levels in head tissue of 'Bravo' cabbage planted 10 June 2002 and 17 June 2003 at the Ohio Agricultural Research and Development Center in Wooster. Values are means of three sub-samples from each of five replications $\pm \mathrm{SE}$.

\begin{tabular}{|c|c|c|c|c|}
\hline Year & $\begin{array}{l}\text { Irrigation } \\
\text { treatment }^{\mathrm{z}}\end{array}$ & Fructose & $\begin{array}{c}\text { Glucose } \\
--\mathrm{mg}^{-\mathrm{g}^{-1}} \text { dry w }\end{array}$ & Sucrose \\
\hline \multirow[t]{4}{*}{2002} & NS & $128.4 \pm 3.1$ & $181.7 \pm 3.9$ & $71.3 \pm 7.0$ \\
\hline & FS & $131.4 \pm 4.5$ & $184.5 \pm 5.6$ & $60.7 \pm 3.7$ \\
\hline & HS & $98.9 \pm 5.2$ & $143.9 \pm 7.4$ & $115.9 \pm 11.1$ \\
\hline & FHS & $99.5 \pm 3.8$ & $140.9 \pm 5.2$ & $90.3 \pm 5.6$ \\
\hline \multirow[t]{7}{*}{2003} & NS & $242.6 \pm 8.9$ & $340.7 \pm 13.0$ & $61.9 \pm 4.4$ \\
\hline & FS & $227.5 \pm 6.1$ & $323.0 \pm 8.2$ & $53.9 \pm 2.7$ \\
\hline & HS & $229.4 \pm 10.0$ & $319.7 \pm 14.0$ & $57.7 \pm 6.0$ \\
\hline & FHS & $241.3 \pm 8.6$ & $334.4 \pm 12.5$ & $67.8 \pm 4.9$ \\
\hline & Year (Y) & $* * *$ & $* * *$ & $* * *$ \\
\hline & Irrigation (I) & $*$ & $* *$ & $* * *$ \\
\hline & $\mathrm{Y} \times \mathrm{I}$ & * & $*$ & $* * *$ \\
\hline
\end{tabular}

$\overline{\mathrm{NSS}}=$ irrigation provided throughout plant development, $\mathrm{HS}=$ irrigation provided during frame development only, FS = irrigation provided during head development only, FHS $=$ no irrigation provided from establishment to harvest.

Ns, ${ }^{*}, * * * * *$ Nonsignificant or significant at $P \leq 0.05,0.01$, or 0.001 , respectively.

head cabbage. Glucobrassicin concentrations were most responsive to $\mathrm{Y}$ and $\mathrm{I}$, and mean total glucosinolate and glucobrassicin concentrations across years were lower in treatments receiving a greater proportion of $\mathrm{ET}_{\mathrm{c}}$ during head development (Fig. 4). The limited influence of year on the methionine-derived glucosinolates resulted in the relationship between aliphatic glucosinolates and $\mathrm{ET}_{\mathrm{c}}$ being less clear (data not shown).

In contrast to glucobrassicin, methionine-derived glucosinolates were lower in FS than in NS plots in 2002 (Table 3). In that year, plants in $\mathrm{FS}$ plots were exposed to greater $\mathrm{ET}_{\mathrm{c}}$ deficits during frame development (12\% of required) than plants in NS plots (39\% of required) (Fig. 1). This previous exposure to stress may have resulted in a lower sensitivity of FS than NS plants to high temperatures and $\mathrm{ET}_{\mathrm{c}}$ deficits that both treatments experienced

Table 3. Glucosinolate (GS) concentrations and analysis of variance for the influence of year and irrigation on GS levels in head tissue of 'Bravo' cabbage planted 10 June 2002 and 17 June 2003 at the Ohio Agricultural Research and Development Center in Wooster. Values are means of three sub-samples from each of five replications \pm SE.

\begin{tabular}{|c|c|c|c|c|c|c|}
\hline \multirow[b]{2}{*}{ Year } & \multirow{2}{*}{$\begin{array}{l}\text { Irrigation } \\
\text { treatment }^{2}\end{array}$} & Total GS & Glucoiberin & Progoitrin & Sinigrin & Glucobrassicin \\
\hline & & \multicolumn{5}{|c|}{ 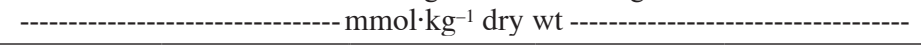 } \\
\hline \multirow[t]{4}{*}{2002} & NS & $24.8 \pm 3.2$ & $9.8 \pm 0.4$ & $1.8 \pm 0.2$ & $6.4 \pm 0.4$ & $3.0 \pm 0.2$ \\
\hline & FS & $20.4 \pm 0.8$ & $9.0 \pm 0.3$ & $1.6 \pm 0.1$ & $5.3 \pm 0.4$ & $3.6 \pm 0.4$ \\
\hline & HS & $33.7 \pm 3.1$ & $12.5 \pm 0.5$ & $3.6 \pm 0.3$ & $9.3 \pm 0.4$ & $8.0 \pm 1.6$ \\
\hline & FHS & $38.2 \pm 2.9$ & $12.6 \pm 0.6$ & $3.7 \pm 0.3$ & $8.4 \pm 0.4$ & $8.7 \pm 0.9$ \\
\hline \multirow[t]{7}{*}{2003} & NS & $21.1 \pm 0.5$ & $8.5 \pm 0.4$ & $1.5 \pm 0.1$ & $7.1 \pm 0.7$ & $1.8 \pm 0.2$ \\
\hline & FS & $21.0 \pm 0.7$ & $8.4 \pm 0.4$ & $1.5 \pm 0.1$ & $6.8 \pm 0.3$ & $2.0 \pm 0.3$ \\
\hline & HS & $22.1 \pm 1.0$ & $10.0 \pm 0.7$ & $1.8 \pm 0.2$ & $7.9 \pm 0.5$ & $2.9 \pm 0.4$ \\
\hline & FHS & $24.6 \pm 1.2$ & $10.0 \pm 0.6$ & $2.1 \pm 0.2$ & $8.8 \pm 0.5$ & $2.7 \pm 0.4$ \\
\hline & Year (Y) & $* * *$ & $* * *$ & $* * *$ & NS & $* * *$ \\
\hline & Irrigation (I) & $* * *$ & $* * *$ & $* * *$ & $* * *$ & $* * *$ \\
\hline & $\mathrm{Y} \times \mathrm{I}$ & $* * *$ & NS & $* * *$ & $* *$ & $* *$ \\
\hline
\end{tabular}

${ }^{2 \mathrm{NS}}=$ irrigation provided throughout plant development, HS = irrigation provided during frame development only, FS = irrigation provided during head development only, FHS = no irrigation provided for the duration from establishment to harvest.

Ns, ${ }^{* * *},{ }^{* * *}$ Nonsignificant or significant at $P \leq 0.05,0.01$, or 0.001 , respectively. during head development in 2002 (Fig.1). Also, plants were exposed to higher temperatures and greater $\mathrm{ET}_{\mathrm{c}}$ deficits during frame development in 2002 than in 2003. Possibly as a result, aliphatic glucosinolate concentrations in NS and FS plots in 2002 were similar to those in HS and FHS plots in 2003 , despite greater $\mathrm{ET}_{\mathrm{c}}$ deficits during head development in 2002. This observation further supports a preconditioning of plants exposed to relatively severe $\mathrm{ET}_{\mathrm{c}}$ deficits during frame development. Preconditioning of plants to drought reduces their sensitivity to heat and drought stress later in development (Chaves et al., 2003; Ladjal et al., 2000). Preconditioning during frame development may be responsible for the weak link between aliphatic glucosinolates and environmental differences between years. The differential response of aliphatic and indole glucosinolates to treatments and $\mathrm{ET}_{\mathrm{c}}$ may be related to differences between the biosynthetic pathways (indole glucosinolates and IAA share a common intermediate, for which they are thought to be competitive) and/or metabolic function of the two groups of glucosinolates (Mikkelsen et al., 2000; Rosa et al., 1997). Auxin levels typically decrease in plants experiencing water-stress, and it is possible that a down regulation of this competing pathway contributes to an increase in the biosynthesis of glucobrassicin and other indole glucosinolates. This would explain the greater sensitivity of glucobrassicin concentrations to Y, I, and ETc.

IMPLICATIONS FOR CABBAGE QUALITY. These data provide a comprehensive assessment of the influence of irrigation timing on cabbage head physiology as it relates to productivity and nutritional and sensory properties. Irrigation as applied in this study was ineffective in consistently meeting $100 \%$ of estimated plant $\mathrm{ET}_{c}$, but it did succeed in generating a range of $\mathrm{ET}_{c}$ deficits. The dence strongly suggests that heading is the developmental stage during which irrigation has the most influence on all indicators of quality observed in this study.

Sugar and glucosinolate concentrations were differentially influenced by irrigation, and these responses were likely relevant to flavor, at least in 2002. In that year, the difference in total glucosinolate concentrations between the treatments receiving irrigation during head development (NS and FS) and the control (FHS) was $15 \mathrm{mmol} \cdot \mathrm{kg}^{-1}$. Radovich et al. (2004c) reported a perceived difference in pungency among cabbage cultivars differing in glucosinolate concentrations by $6 \mathrm{mmol} \cdot \mathrm{kg}^{-1}$. An increase in the perceived pungency of drought stressed cabbage may have been enhanced by lower sugar, particularly fructose, concentrations (Table 2). In a previous test (Radovich et al., 2004b), panelists differentiated between cabbage irrigated at different developmental stages. Although they were 


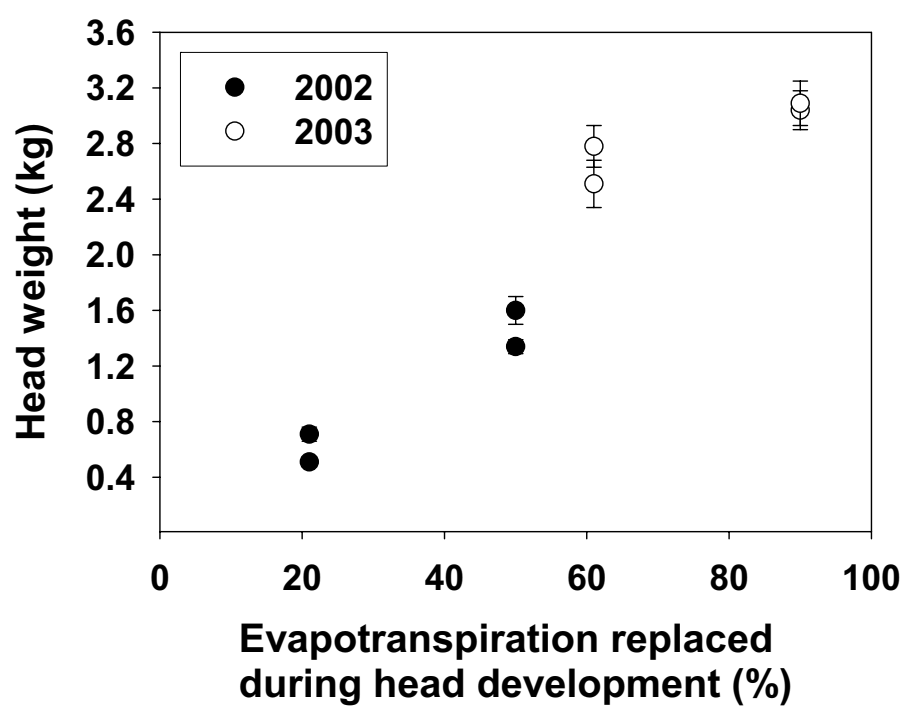

Fig. 2. Mean head weight across treatments and years relative to the proportion of calculated crop evapotranspiration requirement received as rainfall and irrigation during head development in 'Bravo' cabbage planted 10 June 2002 and 17 June 2003 at the Ohio Agricultural Research and Development Center in Wooster. Data points are annual treatment means of 15 values. Error bars are standard errors.

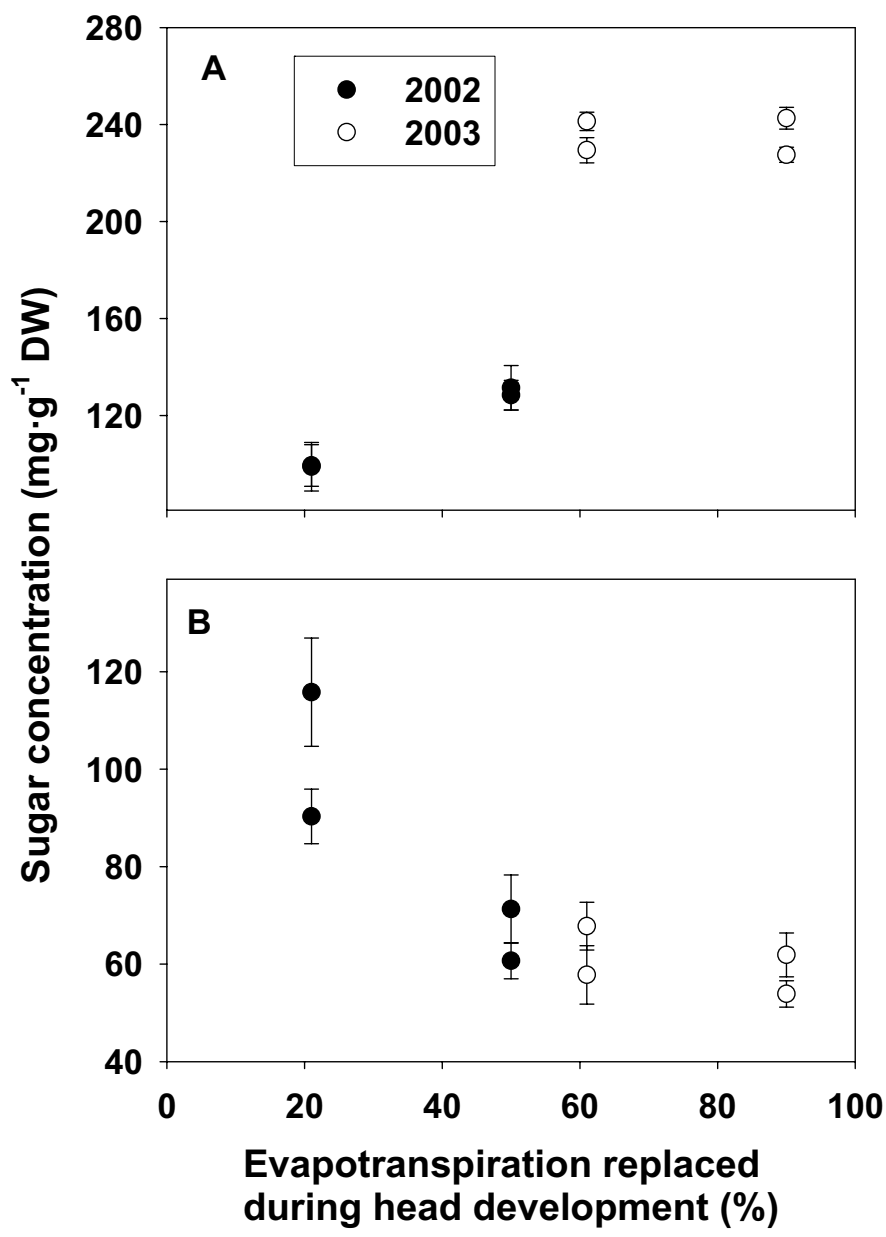

Fig. 3. Mean head fructose (A) and sucrose (B) concentrations across treatments and years relative to the proportion of calculated crop evapotranspiration requirement received as rainfall and irrigation during head development in 'Bravo' cabbage planted 10 June 2002 and 17 June 2003 at the Ohio Agricultural Research and Development Center in Wooster. Data points are annual treatment means of 15 values. Error bars are standard errors.
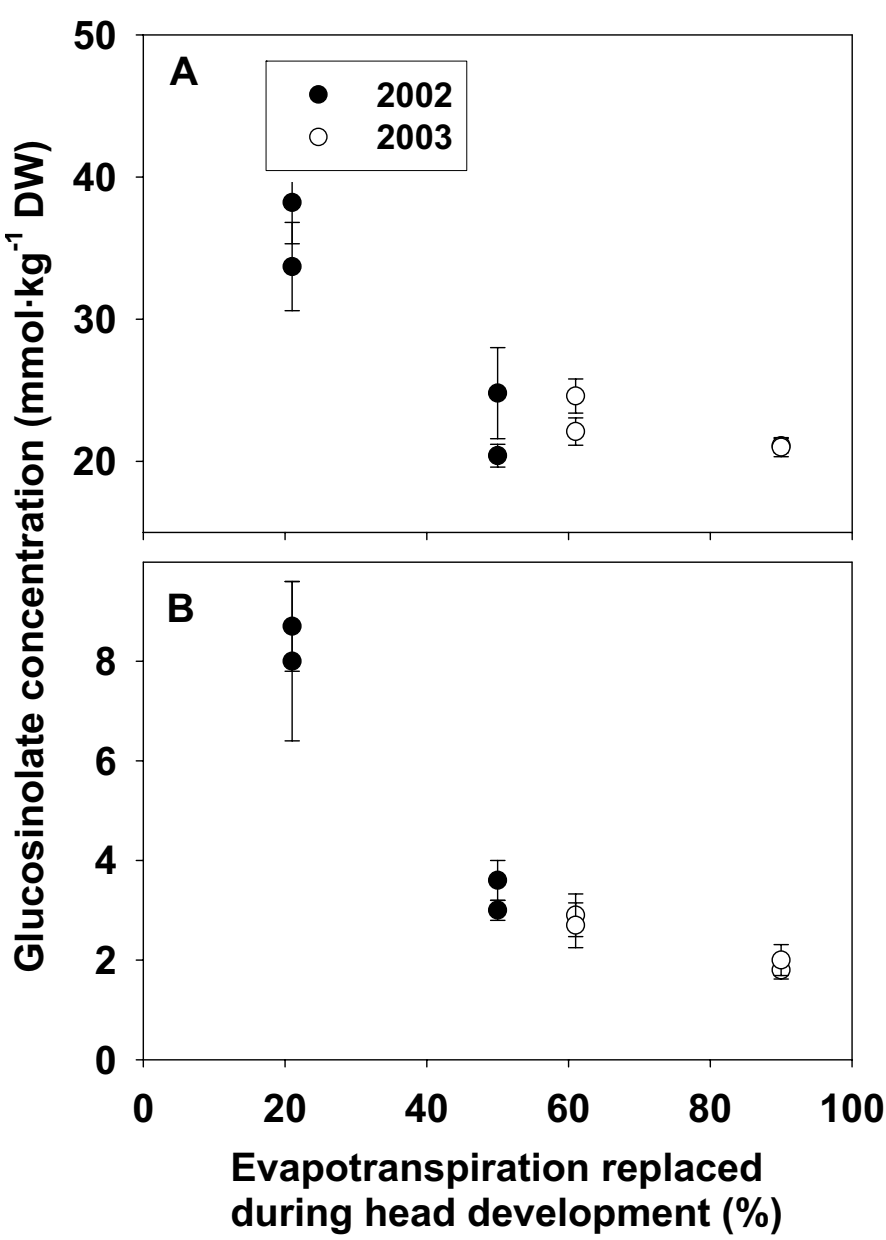

Fig. 4. Mean head total glucosinolate (A) and glucobrassicin (B) concentrations across treatments and years relative to the proportion of calculated crop evapotranspiration requirement received as rainfall and irrigation during head development in 'Bravo' cabbage planted 10 June 2002 and 17 June 2003 at the Ohio Agricultural Research and Development Center in Wooster. Data points are annual treatment means of 15 values. Error bars are standard errors.

not asked to qualify the difference detected, data reported here suggests that variation in pungency and/or sweetness may have been involved. Therefore, Figs. 3 and 4 suggest that supplying at least $50 \%$ of $\mathrm{Et}_{\mathrm{c}}$ during head development may be sufficient to minimize pungency in cabbage, a proportion of $\mathrm{Et}_{\mathrm{c}}$ much lower than that (100\%) suggested for maximizing yield (Fig. 2). This supports the previous suggestion that head physical traits may be more responsive to irrigation than flavor characteristics (Radovich et al., 2004b).

We conclude that supplying irrigation to achieve maximum yield will also optimize sensory quality by minimizing the compounds responsible for pungency and likely increase the perception of sweetness in cabbage. In addition, the potential to predict head weight across irrigation regime based on its stable relationship to size can assist in crop modeling and harvest scheduling to maximize cabbage quality. We also suggest that withholding irrigation may be used to increase glucosinolate concentrations to maximize chemo-protection potential in brassicaceous vegetables, provided that the value added exceeds that lost to yield reduction.

\section{Literature Cited}

Allen, R.G., L.S. Pereira, D. Raes, and M. Smith. 1998. Crop evapotranspiration guidelines for computing crop water requirements. FAO Irrigation 
and Drainage Paper 56. Food and Agriculture Organization of the United Nations, Rome. p. 300.

Bible, B.B., H.Y. Ju, and C. Chong. 1980. Influence of cultivar, season, irrigation, and date of planting on thiocyanate ion content in cabbages. J. Amer. Soc. Hort. Sci. 105:88-91.

Bucks, D.A., L.J. Erie, and O.F. French. 1974. Quantity and frequency of trickle and furrow irrigation for efficient cabbage production. Agron. J. 66:53-57.

Buttery, R.G., D.G. Guadagni, L.C. Ling, R.M. Seifert, and W. Lipton. 1976. Additional volatile components of cabbage, broccoli and cauliflower. J. Agr. Food Chem. 24:829-832.

Champolivier, L. and A. Merrien. 1996. Effects of water stress applied at different growth stages to Brassica napus L. var. oleifera on yield, yield components and seed quality. Eur. J. Agron. 5:53-160.

Charron, C.S. and C.E. Sams. 2004. Glucosinolate content and myrosinase activity in rapid-cycling Brassica oleracea grown in a controlled environment. J. Amer. Soc. Hort. Sci. 129:321-330.

Chaves, M.M., J.P. Maroco, and J.S. Pereira. 2003. Understanding plant responses to drought- from genes to the whole plant. Functional Plant Biol. 30:239-264.

Fahey, J.W., A.T. Zalcmann, and P. Talalay. 2001. The chemical diversity and distribution of glucosinolates and isothiocyanates among plants. Phytochemistry $56: 5-51$.

Freeman, G.G. and N. Mossadeghi. 1973. Studies on the relationship between water regime and flavour strength in watercress (Rorippa nasturtiumaquaticum (L) Hayek), cabbage (Brassica oleracea capitata) and onion (Allium cepa). J. Hort. Sci. 48:365-378.

Gonzalez, E.M., A.J. Gordon, C.L. James, and C. Arrese-Igor. 1995. The role of sucrose synthase in the response of soybean nodules to drought. J. Expt. Bot. 46:1515-1523.

Heaney, R.K. and G.R. Fenwick. 1981. A micro-column method for the rapid determination of total glucosinolate content of cruciferous material. Zeitschrift Pflanzenzuchtg 87:89-95.

Heermann, D.F., D.L. Martin, R.D. Jackson, and E.C. Stegman. 1990. Irrigation scheduling controls and techniques, p. 509-535. In: B.A. Stewart and D.R. Nielsen (eds.). Irrigation of agricultural crops. Agron. Monograph No. 30, Amer. Soc. Agron., Madison, Wis.

Hochmuth, G.J. 2003. Progress in mineral nutrition and nutrient management for vegetable crops in the last 25 years. HortScience 38:999-1003.

ISO. 1992. Rapeseed determination of glucosinolates content. Part 1: Method using high-performance liquid chromatography. International Standard ISO 9167-1. Intl. Organization for Standardization, Geneva, Switzerland.

Janes, B.E. 1950. The effect of irrigation, nitrogen level and season on the composition of cabbage. Plant Physiol. 25:441-452.

Jiang, Y. and B. Huang. 2001. Physiological responses to heat stress alone or in combination with drought: a comparison between tall fescue and perennial ryegrass. HortScience 36:682-686.

Kleinhenz, M.D. 2003. A proposed tool for preharvest estimation of cabbage yield. HortTechnology 13:182-185.

Kleinhenz, M.D. and A. Wszelaki. 2003. Yield and relationships among head traits in cabbage (Brassica oleracea, L. Capitata Group) as influenced by planting date and cultivar I. Fresh market. HortScience 38:1349-1354.

Klocke, N.L. and P.E. Fischbach. 1984. Estimating soil moisture by appearance and feel. Guide B-12. Coop. Ext. Serv., Inst. Agr. Natural Resources, Univ. of Nebraska, Lincoln.

Kuchenbuch, R., H. Auerswald, B. Bruckner, and A. Krumbein. 1999. Use of sensory analysis for fresh vegetables. Acta Hort. 483:221-223.

Ladjal, M., D. Epron, and M. Ducrey. 2000. Effects of drought preconditioning on thermotolerance of photosytem II and susceptibility of photosynthesis to heat stress in cedar seedlings. Tree Physiol. 20:1235-1241.

Lester, G.E. and K.M. Crosby. 2002. Ascorbic acid, folic acid, and potassium content in postharvest green-flesh honeydew muskmelons: Influence of cultivar, fruit size, soil type, and year. J. Amer. Soc. Hort. Sci. 127:843-847.

Mailer, R.J. and P.S. Cornish. 1987. Effects of water stress on glucosinolate and oil concentrations in the seeds of rape (Brassica napus L.) and turnip rape (Brassica rapa L. var silvestris [Lam.] Briggs). Aust. J. Expt. Agr. 27:707-711.

Martens, M. 1985. Sensory and chemical quality criteria for white cabbage studied by multivariate analysis. Lebensmittel Wissenschaft und Technologie 18:100-104.
Mikkelsen, M.D., C.H. Hansen, U. Wittstock, and B.A. Halkier. 2000. Cytochrome P450 CYP79B2 from Arabidopsis catalyzes the conversion of tryptophan to indole-3-acetaldoxime, a precursor of indole glucosinolates and indole-3-acetic acid. J. Biol. Chem. 275:33712-33717.

Nelson, S.H. and K.E. Hwang. 1976. Water usage by cabbage plants at different stages of growth. Can. J. Plant Sci. 56:563-566.

The Ohio State University. 2003. The OARDC weather system. Ohio Agricultural Research and Development Center, Wooster. 28 July 2003. $<\mathrm{http} / / / w w w . o a r d c . o h i o-s t a t e . e d u / c e n t e r n e t / h t m>$.

Pereira, F.M.V., E. Rosa, J.W. Fahey, K.K. Stephenson, R. Carvalho, and A. Aires. 2002. Influence of temperature and ontogeny on the levels of glucosinolates in broccoli (Brassica oleracea var. italica) sprouts and their effect on the induction of mammalian phase 2 enzymes. J. Agr. Food Chem. 50:6239-6244.

Radovich, T.J.K., M.D. Kleinhenz, A. Sanchez-Vela, J.C. Scheerens, and B. Schult. 2003. Fresh cabbage sensory quality: Components and the impact of production factors. Acta Hort. 628:787-795.

Radovich, T.J.K. and M.D. Kleinhenz. 2004. Rapid estimation of cabbage head volume across a population varying in head shape: a test of two geometric formulae. HortTechnology 14:388-391.

Radovich, T.J.K., M.D. Kleinhenz, J.G. Streeter, A.R. Miller, and J.C. Scheerens. 2004a. Planting date affects total glucosinolate concentrations in six commercial cultivars of cabbage (Brassica olereacea L., Capitata Group). HortScience 40:106-110.

Radovich, T.J.K., M.D. Kleinhenz, J.F. Delwiche, and R.E. Liggett. 2004b. Triangle tests indicate that irrigation timing affects fresh cabbage sensory quality. Food Quality \& Preference 15:471-476.

Radovich, T.J.K., M.D. Kleinhenz, and N.J.Honeck. 2004c. Important cabbage head traits at five points in development. J. Veg. Crop Prod. 10:19-32.

Roitsch, T. 1999. Source-sink regulation by sugar and stress. Curr. Opin. Plant Biol. 2:198-206.

Rosa, E.A.S., R.K. Heaney, C.A.M. Portas, and G.R. Fenwick. 1996. Changes in glucosinolate concentrations in Brassica crops (B.oleracea and B. napus) throughout growing seasons. J. Sci. Food Agr. 71:237-244.

Rosa, E.A., R.K. Heaney, G.R. Fenwick, and C.A.M. Portas. 1997. Glucosinolates in crop plants. Hort. Rev. 19:99-215.

Rosa, E., M. David, and M.H. Gomes. 2001. Glucose, fructose and sucrose content in broccoli, white cabbage and Portuguese cabbage grown in early and late seasons. J. Sci. Food Agr. 81:1145-1149.

Rosenfeld, H.J. 1999. Quality improvement of vegetables by cultural practices. Acta Hort. 483:57-66.

Sanchez, C.A., R.L. Roth, and B.R. Gardner. 1994. Irrigation and nitrogen management for sprinkler-irrigated cabbage on sand. J. Amer. Soc. Hort. Sci. 119:427-433

Singh, R. and R.B. Alderfer. 1966. Effects of soil-moisture stress at different periods of growth of some vegetable crops. Soil Sci. 101:69-80.

Snyder, R.L. and S. Eching. 2004. Daily reference evapotranspiration (ET) calculator._Dept. of Land, Air and Water Resources, Univ. of California, Davis, 11 June 2004. <http://biomet.ucdavis.edu/>.

Streeter,J.G. and C.E. Strimbu. 1998. Simultaneous extraction and derivatization of carbohydrates from green plant tissues for analysis by gas-liquid chromatography. Ann. Biochem. 259:253-257.

Swiader, J.M., G.W. Ware, and W.H. Shoemaker. 2002. Irrigation and mulching, p. 145-162 In: J.M. Swiader and G.W. Ware (eds.). Producing vegetable crops. Interstate Publishers, Danville, Ill.

Tiwari, K.N., A. Singh, and P.K. Mal. 2003. Effect of drip irrigation on yield of cabbage (Brassica oleracea L. var. Capitata) under mulch and non-mulch conditions. Agr. Water Mgmt. 58:19-28.

Van Doorn, H.E., G.C. van der Kruk, G.J. van Holst, N.C.M.E. RaaijmakersRuijs, E. Postma, B. Groeneweg, and W.H.F. Jongen. 1998. The glucosinolates sinigrin and progoitrin are important determinants for taste preference and bitterness of brussels sprouts. J. Sci. Food Agr.78:30-38.

Van Etten, C.H., M.E. Daxenichler, H.L. Tookey, W.F. Kwolek, P.H. Williams, and O.C. Yoder. 1980. Glucosinolates: Potential toxicants in cabbage cultivars. J. Amer. Soc. Hort. Sci. 105:710-714.

Wszelaki, A. and M.D. Kleinhenz. 2003. Yield and relationships among head traits in cabbage (Brassica oleracea, L. Capitata Group) as influenced by planting date and cultivar II. Processing. HortScience 38:1355-1359.

Yano, M., H. Itoh, and R. Saijo. 1987. Allyl isothiocyonate and its contribution to pungency in cabbage. J. Food Sci. Technol. (Japan) 34:608-611. 